\title{
The Factors that Affect the Dividend Policy of the Greek Listed Firms Prior to the Economic Crisis: A Comparison to Nyse, Nasdaq, Norwegian and U.K. Firms"
}

\author{
${ }^{1}$ Eriotis, N., ${ }^{2}$ P. Kaldis, ${ }^{3}$ E. Poutos and ${ }^{4}$ D. Vasiliou \\ ${ }^{1}$ National and Kapodistrian University of Athens, Greece \\ ${ }^{2}$ Technological Educational Institute of Athens, Egaleo, Greece \\ ${ }^{3}$ National and Kapodistrian University of Athens, Greece \\ ${ }^{4}$ Hellenic Open University, Patra, Greece
}

Received 2014-02-07; Revised 2014-03-17; Accepted 2014-06-03

\begin{abstract}
This study presents, analyzes and compares the factors affecting the dividend policy of the Greek listed firms, prior to the Greek economic crises, to NYSE, NASDAQ, Norwegian and U.K. firms. Our empirical investigation has a dual objective, to record the dividend policy of the Greek firms and to compare their dividend choices to other, more financially mature, markets. We sent to all Athens Exchange listed firms a detailed questionnaire concerning their dividend choices. Our findings proved to be very interesting since the average listed Greek firm shares the same opinion with the average firm of the compared studies in the following areas: Price affection, risk bearing, past dividends' pattern and agency costs. Some of our findings proved to be quite close with some of the results of the compared studies in the following subjects: The sector of the company, the target payout ratio, the financing ability and the information content of dividends. Finally, some of our findings are in contradiction to some of the results of the previous studies, these are: The impact of taxation on dividends and the legislation framework.
\end{abstract}

Keywords: Corporate Finance, Dividends, Greek Firms

\section{INTRODUCTION}

The dividend policy remains one of the controversial problems in corporate finance. No matter how many academics and practicians have tackled with payout policy, a general solution seems to be inexistent. Even though a unique solution seems not to exist, there is strong evidence that dividend policy is a puzzle (Black, 1976; Baker et al., 2002) and the final choice is a product of complex decision making based on parameters that vary with time, place and conditions (Poutos, 2009). During the last fifty years many theories have been developed taking into account a number of different parameters that affect dividend policy. These parameters involve the firm's objectives, the investors' desires and choices, the creditors constrains and the country's institutional foundations (Allen and Michaely, 1995); Frankfuter and Junior, 2002, 2002).

Resent researches (Fama and French, 2001; Denis and Osobov, 2008) provide us with evidence supporting that the proportion of firms that pays dividends, worldwide, has been decreased. Additionally, Twu (2012) finds that «...stock market development makes firms in countries with a relatively high dependence on stock market financing less likely to pay dividends, to pay less and more likely to omit». It is true that nowadays the global economy faces an economic crisis which has already affected many countries and has great impact on financial markets. Under this economic environment, where there are limited and expensive opportunities, we wonder if the dividend policy of the firms remains an Corresponding Author: Eriotis, N., National and Kapodistrian University of Athens, Greece 
important corporate parameter. According to Fuller and Goldstein (2011) «... dividends do matter to shareholders, but more in declining markets than advancing ones». Payout decision making affects not only the firm but the shareholders, debt holders and managers as well; thus, dividend policies were, are and will be an important corporate parameter. Given that the global financial system is dynamic, the values of the assets are changing continuously and generate, sometimes (like nowadays financial crisis), extreme changes in our wealth. These continuous changes in prices affect either positively or negatively the value of the capital; the only source of zero or positive returns is the dividend payments, which, normally, follow the fluctuations of corporate earning and the changes in corporate investment policy (Lintner, 1956; Fama and Babiak, 1968; Nakamura and Nakamura, 1985). Today's financial crisis resulted in rapid changes in the value of the capital and now the main source of positive returns is the distribution of the earnings. Thus, dividend payments act as a loss minimizer source and can actually help to recover from the trough stage of the economy.

During the last fifteen years, researches (Poutos, 2009; Kalantonis and Zopounidis, 2009) have enriched their empirical investigations with qualitative information that take into account parameters that cannot be measured by quantitative data, such as the goals of the firm's directors, the maximization problem of the investors, the source of financing, the economic environment, innovative investments disclosure and the country's law boundaries. Our methodology and empirical investigation is based on qualitative data concerning the dividend policy of the firms. Specifically, we analyze the dividend policy of the Greek firms and we compare our results to other empirical investigations which use qualitative data. Thus, the objective of this study is to investigate the differences in dividend policies between the Greek firms and other countries with different levels of financial maturity.

The structure of this study is organized as follows. In the next chapter we briefly present the dividend policy theories and categorize them in five distinct areas. In section three we present our methodology and our findings, which have been organized base on the five categories of section two. In section four we compare our findings with four other empirical investigations concerning the NYSE, NASDAQ, British and Norwegian firms. Finally, in section five we present our conclusion.

This template, created in MS Word 2003 and saved as "Word 97-2003 \& 6.0/95-RTF" for the PC, provides authors with most of the formatting specifications given in the instructions to authors and needed for preparing electronic versions of their papers. All standard paper components have been specified for three reasons: (a) ease of use when formatting individual papers, (b) automatic compliance to electronic requirements that facilitate the production of electronic products and (c) conformity of style throughout a journal paper. Margins, column widths, line spacing and type styles are built-in. Examples of the type styles are provided throughout this document and are identified in italic type, within parentheses.

\section{LITERATURE REVIEW}

We consider dividend policy as a complex decision making which involves the firm and all the parties that the firm collaborates with. We recognize that dividend payout decision is a corporate choice which affects the firm in two ways. The first involves the dividend choice and how this decision affects the third parties of the firm. The second refers to the reaction of all the third parties affected by this dividend decision and how this reaction affects back the firm. Using this approach we distinguish the dividend policy in five major areas of analysis and we associate dividend policy with (a) the value of the firm, (b) the corporate dividend policy decisions, as these were first introduced by Lintner (1956), (c) the information content of dividends, (d) the agency cost and (e) the economic environment, such as taxation, legal constrains and inflation.

\subsection{The Value of the Firm}

It is generally accepted that the objective of the firm is to maximize the shareholders utility, which, (under the assumption that shareholders do not participate in the management team and their only source of satisfaction is the realized earnings) can be expressed by the maximization of the firm's value. There are numerous researches Lease et al. (2000) (theoretical and empirical) that refer to the relationship between the value of the firm and its dividend policy. According to this theoretical context three schools of thoughts came up with their suggestions. The first implies that there is a positive relationship between dividend and value (Gordon, 1963; Lintner, 1962), the second that this relationship is negative (Litzenberger and Ramaswamy, 1979) and the third that there is no relationship between them (Miller and Modigliani, 1961).

Miller and Modigliani (1961) introduced their dividend irrelevance theory explaining why dividend policy can not affect the value of the firm. Their primary work was supported not only by themselves but also by a number of researchers (see Black and Scholes, 1974; Miller and Scholes, 1978; Miller, 1986). For further 
references, (Frankfuter and Junior, 2002; Allen and Michaely, 1995). Even though their irrelevance theory is proved in a controlled economic environment, the restrictions that they imposed, concerning the efficiency of the market and the behavior of the investors, describe the reasons why dividend policy affects the value of the firm in our economies. Nowadays, dividend policy research has empirically revealed that there is a strong relation between dividend policy and the firm's value and the irrelevance theory seems to be only a valuable result on corporate finance. A recent article by DeAngelo and DeAngelo (2006) reveals that irrelevance theory stands not only because of the assumptions that Miller and Modigliani state, but also because Miller and Modigliani followed a specific dividend policy, known as residual theory according to which the firm distributes all the free cash flow to shareholders.

In contrast to dividend irrelevance theory, a series of empirical investigations has been contacted supporting that there is a positive relationship between dividend and firm's value. Lintner (1962; Gordon, 1963) are the primary supporters of the theory, which suggests that the more money the firm pays as dividend the more valuable it becomes. This theory is known as the bird in the hand theory and considers that earnings distribution through dividend payments bear less risk than earnings retention. Under this theory, the money, which is directed to shareholders, is more valuable than the money that is reinvested by the firm. More than that, dividend payment reduces the investor's transaction cost, since the investor does not have, in order to liquidate his earnings, to sell in the market the correspondent amount of shares. Recent empirical studies (Lease et al., 2000; Baker et al., 1985; Dhanani, 2005), in relative areas, indicate that according to managers, dividend payment is positively related to the value of the firm. Additionally, Dyl and Weigand (1998) found that when a firm starts to pay dividends the firm's earnings and cash flows become less risky.

On the contrary, when tax on dividend income is imposed, the value of the dividend payment is reduced. Since the majority of countries' tax system involves taxes on dividends, the assumption that dividends affect negatively the value of the firm is a realistic one. It is true that when dividend is taxed its real value is decreased and the investor faces a reduction on his potential income. It is wrong to fully support that when tax on dividend is imposed, a strictly negative relationship between share price and dividend exists. It is common on developed countries to tax not only the dividend payments, but also the capital gains, as well. Under this situation, we recognize that when dividends tax is greater than the capital gains tax plus the transaction cost of share selling, the negative relationship between dividend and firm's value must be held. An additional argument supporting the negative impact of dividend is that even though the sum of capital gains tax and the cost of share selling is greater than the dividend tax, the investor can choose the appropriate time to liquidate his dividend through share selling.

\subsection{Corporate Dividend Policy Decision}

Even though there is strong evidence that dividend policy affects share price, the relationship between them can not reveal the factors that affect the corporate payout decision making. In his influential work on dividend policy, Lintner (1956), suggests his famous corporate behavioural model, according to which, changes in dividend payments depend on the level of current earnings and the last year's dividend payment of the firm. Lintner's (1956) econometric model and his findings constitute the cornerstone of dividend policy analysis. Fama and Babiack (1968; Nakamura and Nakamura, 1985; Benartzi et al., 1997) are just few of the numerous researchers (For further references, (Frankfuter and Junior, 2002; Allen and Michaely, 1995) who follow the steps of Lintner by extending and adjusting his theory to their research requirements.

Explanations based on firm's dividend choice do not only include the two factors model suggested by Lintner's, but also all the factors that these two variables implicate. In more detail, the firm has a long term dividend payout target ratio according to which the firm adjusts its payments. The fundamental assumption on target payout ratio is that the firm does not adjust its dividend on target rapidly; on the contrary, it chooses to alter the dividend through time by smoothing dividend payments. According to this theory, the dividend smoothing is the key on payout policy of the firm which wants to minimize the investor's uncertainty about his cash returns from his investment.

\subsection{Information Content of Dividend}

The dividend information theory is based on the fact that capital markets are not fully efficient since there are market parties that are more informed than others. The assumption that managers, in individual cases, are more informed than the market, is coherent with the market efficiency theory; according to dividend information theory, the firm uses its dividend policy, not only as an earnings transfer mechanism, but as an information carrier as well. The firm uses its dividend policy in order to reveal information concerning the value of the firm, its 
potential earnings and the quality of the investments that has undertaken. We can consider information content of dividend as an important justification for the firm to pay dividends, even in markets where taxes operate against dividends (For further analysis see Lease et al., 2000).

The use of dividend as information vehicle is important, when the firm has motives to reveal its true value in the market. In such a context, dividend policy is a strong instrument to ensure the market for the quality and the value of the firm. The dividend information mechanism can also be used by firms in order to control its financial status and inform the market about the firm's potentials. There is a great deal of debate in literature on the importance of dividend signaling theory, since empirical evidence support both the validity (For example see Balachandran and Nguyen, 2004; Beer, 1993; Brook et al., 1998; Lipson et al., 1998; Fuller and Benjamin, 2010) and the rejection (For example see: DeAngelo et al. (1996; 2000; Yoon and Starks, 1995 and Bernhart et al., 2005) of dividend information content.

\subsection{Agency Theory and Dividend Policy}

Given that the firm is a complicated organization, where numerous parties participate, we expect that a conflict among these parties is probable. In such a context, we address two main types of conflicts. On one hand, there are differences between investors and firms, which are expressed by management team and on the other conflicts between firms and firms' debtors. Dividend agency theory refers to these conflicts and argues that dividend policy can be used as a conflict manipulation tool.

The first type of conflicts explores the relationship between the investor, who wants to maximize his investment utility and the firm's objectives, as they are implemented by the management team's aims and intentions. The collision between these two parties concerns the manipulation of the free cash flow. The management team wants to use the free cash in order to serve its corporate goals, which may not be in line with the investor's utility (See, Easterbrook, 1984; Jensen, 1986). The management team wants to increase the available capital because free cash boosts its flexibility. On the contrary, the investor does not want an independent management team since it is more difficult and expensive to control it. A high dividend helps to control management team easily and inexpensively since without free cash the firm has to borrow from the markets; that is how the investor transfers the monitoring costs to lender.

The second type of conflicts investigates the relationship between the firm, which wants to maximize its efficiency and the debtors, who want both, to collect their capital and to minimize the probability of the firm's defaulting. Under these circumstances debtors do not want the firm to pay dividends as this practice decreases the availability of cash and transfers their money to shareholders (Lease et al., 2000). According to Kalay $(1982 \mathrm{a} ; 1982 \mathrm{~b})$ in some cases debtors try to impose dividend restrictions (Also see, Fildeck and Mullineaux, 1999) in order to protect their money.

\subsection{Economic Environment and Dividend Policy}

The firm has to operate in a bounded economic environment where taxes (See, Brennan, 1970; Kalay and Michaely, 1993; Elton and Gruber, 1970) are imposed, corporate laws are enforced and market dynamics dominate, no matter how big, wealthy and well organised the firm is. The firm has to adjust its corporate dividend policy according to the economic environment. An implementation of a new tax on dividends affects the payout policy of the firm, since the income of the shareholders is affected too. The high importance of the economic environment is obvious in case of high inflation. As prices increase the volume of the firm, sales, the net earnings, are increased too; consequently the dividend payments have to be adjusted too in order to keep the shareholder's income in the same level.

\section{DATA COLLECTION AND EMPIRICAL FINDINGS}

\subsection{Data Collection}

Our empirical investigation was conducted based on previeous researches concerning the dividend policy, which they use questionnaires as their primary data source. We chose to use questionnaires in our empirical investigation since dividend policy and payout decision making is a complicated choice, which affects the performance of the firm and vice versa. Corporate performance is affected by many factors such as investment opportunities, return and risk, the earnings of the firm, cost of the capital, capital structure, economic environment, inflation, capital and money markets, the objectives of the shareholders, the decisions of the management team and many other parameters that can either be measured by quantitative data (e.g., earnings) or qualitative data (e.g., the shareholders' investment choices). Thus, a simple or a multiple regression model is unable to capture all the financial parameters that affect the firm's final choice. That is why we chose to use questionnaire in our empirical investigation. 
We focus our investigation in the Greek firms listed on Athens Stock Exchange (ASE). More specifically, we sent out, to all Greek firms listed on the Athens Exchange, a detailed questionnaire concerning their dividend policy. The questionnaire was filled and sent back during the period of January 2004 until 31st of May 2004. Prior to sending, the questionnaire was tested by a panel of experts, resulting in minor adjustments, where necessary. The responded rate of the questionnaire appears to be fairly high. From the 355 enterprises listed on the Athens Exchange, 121 questionnaires were filled in and sent back, that is the $34.1 \%$ of total firms listed in Athens Exchange. We would probably have managed to collect a greater amount of questionnaires if we had chosen to send a less detailed questionnaire. However, our primary aim was to gather as much information as possible, so that we could derive complemented and reliable results and conclusions. There are two main reasons that firms did not reply to our questionnaire. The first reason of not responding was work load and no time to answer and the second was the information-discloser policy of some firms. One could argue that our results may suffer from "consistency". The payout policy of the non-respondent firms could differ from the one of the respondent. Since it was impossible to collect answers from all listed companies, it is better to possess detailed information at least from the $34.1 \%$ of the total listed firms. Additionally, we performed an $\mathrm{x}^{2}$-test comparing the mean payout ratio of the respondent firms to the mean payout ratio of all the firms listed in ASE, which resulted in no difference in the mean payout ratio among them.

\subsection{Empirical Findings \\ 3.2.1. The Value of the Firm}

According to theoretical and empirical models (see section 2) the market value of the firm is directly linked to profits and by extension to dividend payments. In question 1 (Table 1) we asked the Greek firms: (Q1) does the payout policy of the firm affect its share price? According to them the $60.5 \%$ of businesses reported that dividends affect the value of their shares, the $30.3 \%$ does not affect them, while the $9.2 \%$ of the firms did not want to answer our question, probably not to disclose any information relevant to their market value. This first result is in contrast to the theoretical approach of MM (1961) about dividend irrelevance, but in line with Lintner (1956) and many other researches such as Baker et al. (1985). As sub-question to Q1, we asked those who supported that the dividend affects the value of the firm (Q1.1) (Table 3): "Why dividends affect the value of the firm?" The $40.8 \%$ of the 76 firms, that answered this question, supports that dividends affect the value of the firms due to the reduced risk that dividends bear, the $23.6 \%$ due to taxes and the remaining $32.9 \%$ for other reasons, which they did not specify. These findings are in line with both, Gordon (1963), differences in risk levels between dividends and capital gains and Elton and Gruber (1970), the tax impact on dividends. The next question was set to reveal how effectively the managers believe they can use the dividend policy to affect the share price. Q2 (Table 2): "Note the relative importance of the following statement, in determining the dividend policy of the firm: Strong interest of maintaining or increasing the firm's share price." The $79.4 \%$ of the firms considers that dividends can be used in order to maintain or increase the firm's share price. This answer is in line with Frankfurter and Lane (1992), who support the idea that managers know the investors' preferences for dividends and they use them in order to minimize the investors' doubts about their investment future. Q3 (Table 2) refers to the relative importance of the following statement: (The management team should meet the preferences of shareholders on dividends". 46 of the 121 firms rank the importance of this statement from sufficiently important to less important. Additionally, 45 firms ranked this statement as of moderate importance to the dividend policy and 28 firms as of little or no importance.

One other parameter that plays an important role in the relationship between dividends and firms value is how the managers and investors rate the risk of dividend payments and capital gains. Q4 (Table 5) asked the management team: "Do your shareholders believe that the dividends paid by the firm have different risk than capital gains (which come from the reinvestment of undistributed profits)?" According to our findings, the $58.7 \%$ of the firms indicate that shareholders believe that dividends are less risky than capital gains, the $34.5 \%$ that there is no difference in risk between them and the remaining $6.7 \%$ that dividends are riskier compared to capital gains. These results are in line with other empirical studies, such as Gordon (1963) and Baker et al. (1985), who support the safer version of dividend payments. The following question focuses on the empirical result that there is less risk in dividend payments and asks, (Q5) (Table 2): "To what extent, do you think that investors have different perceptions about the risk of dividends in relation to retained earnings?" From the responses we received the $12.4 \%$ of the firms responded that investors believe that there is no difference in risk bearing, the $24.0 \%$ they believe a small difference exists, the $44.6 \%$ a moderate difference, the $9.9 \%$ a high difference and the $1.7 \%$ a very high difference. 
Table 1. Answers

\begin{tabular}{lllll}
\hline Question & Yes & No & Non answered & Total \\
\hline Q1 & 72 & 36 & 13 & 121 \\
Q12 & 52 & 58 & 11 & 121 \\
Q21 & 30 & 61 & 30 & 121 \\
Q22 & 32 & 59 & 30 & 121 \\
Q23 & 67 & 27 & 27 & 121 \\
Q24 & 63 & 4 & 54 & 121 \\
Q25 & 87 & 17 & 17 & 121 \\
Q26 & 80 & 4 & 37 & 121 \\
\hline
\end{tabular}

Table 2. Answers

\begin{tabular}{lrrrrrll}
\hline & & & & \multicolumn{3}{l}{ Non } \\
Question & \multicolumn{1}{r}{ Low } & & & & High & \multicolumn{2}{l}{ answered } \\
& 10 & 12 & 40 & 40 & 16 & 3 & 121 \\
Q3 & 4 & 24 & 45 & 33 & 13 & 2 & 121 \\
Q5 & 15 & 29 & 54 & 12 & 2 & 9 & 121 \\
Q6 & 9 & 19 & 48 & 26 & 15 & 4 & 121 \\
Q9 & 6 & 14 & 23 & 51 & 20 & 17 & 121 \\
Q10 & 11 & 19 & 37 & 39 & 12 & 3 & 121 \\
Q11 & 12 & 24 & 33 & 36 & 11 & 5 & 121 \\
Q14 & 3 & 8 & 52 & 42 & 14 & 2 & 121 \\
Q15 & 22 & 18 & 24 & 34 & 18 & 5 & 121 \\
Q16 & 15 & 16 & 40 & 32 & 13 & 5 & 121 \\
Q17 & 6 & 10 & 16 & 45 & 41 & 3 & 121 \\
Q18 & 4 & 9 & 21 & 49 & 36 & 2 & 121 \\
Q19 & 9 & 34 & 36 & 27 & 11 & 4 & 121 \\
Q20 & 23 & 48 & 26 & 18 & 5 & 1 & 121 \\
Q27 & 2 & 3 & 23 & 50 & 41 & 2 & 121 \\
Q28 & 25 & 20 & 36 & 26 & 9 & 5 & 121 \\
Q29 & 14 & 22 & 41 & 29 & 11 & 4 & 121 \\
Q30 & 12 & 20 & 31 & 28 & 24 & 6 & 121 \\
Q31 & 22 & 30 & 37 & 22 & 5 & 5 & 121 \\
\hline
\end{tabular}

In the final question of this section (Q6) (Table 2) we ask the managers: "To what extent the administration of the firm meets the dividend preferences of the shareholders?" The $23.9 \%$ considers that they do not respond successfully to shareholders dividend preference, whereas the $41 \%$ believes that its response to shareholders dividend preference is in moderate level, the $22.2 \%$ a high response and the $12.8 \%$ a very high response.

\subsection{Corporate Dividend Policy Decisions}

According to our findings presented in the previews section (section 3.2.2) the firm is, or at least can be, affected by the dividend policy of the firm. The main problem is to determine the factors that affect the dividend policy. In his primary work John Lintner (1956) proposed his dividend policy model and analyzed the dividend choice of the firm based on the fundamentals of the firm. In our empirical investigation we separated the corporation's dividend decision making in two time intervals, the short run and the long run and we tested most of Lintner's ideas by questioning the management team of the firms. Our opinion is that dividend decision making affects firms' value in the long run, through consistent financing by retained earnings.

In the short run, necessary adjustments have to be done. Focusing on the short run dividend decision making, we asked the Greek firms (Q7) (Table 6): "What was the firm's payout ratio last year?" Our findings proved to be very interesting since the $72 \%$ of the firms had payout ratio lower than $40 \%$. Even though the $72 \%$ is high, it is not surprising, since the distribution of earnings includes payments to the board of directors, reserves accounts according to the Greek law and the company's statute as well as the withholding of a portion of earnings. It is important to note that the $29 \%$ of the Greek firms chooses a dividend payment between $0 \%$ $10 \%$ of the net earnings and the $21.5 \%$ between $30 \%$ $40 \%$. Another interesting result is that from the 121 firms 3 of them had dividend payout ratio greater that $100 \%$, which means that they chose to liquidate a portion of the existing shareholders' equity.

In the short run there are a lot of disturbances that do not allow the firm to keep its dividend payment to desirable levels. On the contrary, given that the perspectives of the market are known, the firm has to adjust its dividend payment accordingly. In the next question (Q8) (Table 7) we asked the firms: "Which of the following short term (i.e. from year to year) dividend policies is implemented by the company?" From the 121 companies almost the $24 \%$ (i.e., 29 companies) state that they do not follow a specific dividend policy in the short run, on the contrary the remaining $76 \%$ noted that they follow a distinct dividend policy based on which they determine their next dividend payment. The $33.1 \%$ of the 121 firms noted that, in the short run, they decide to distribute a constant portion of their realized earnings and as a result the amount of money paid to shareholders follow the fluctuations of the realized earnings. The $11.6 \%$ of the firms choose to pay a constant amount of money per share, the $16.5 \%$ of them reply that they increase the dividend payment per share with a constant rate and the $10 \%$ of them they follow a different short term dividend policies without specifying them.

We have seen that the realized earnings of the firm affect its final dividend decision. Our findings are consistent with those of Lintner's (1956) and many other recent researches based on his observations (see section 2 ), which means that dividends might be a product of the firm's earnings. In question 9 (Q9) (Table 2) we asked the firms to ... "Rate the importance of the future earnings in your dividend payments". 
Table 3. (Q1.1)

\begin{tabular}{|c|c|c|c|c|c|}
\hline Answers & $\begin{array}{l}\text { To the different risk } \\
\text { between dividends } \\
\text { and retained earnings }\end{array}$ & $\begin{array}{l}\text { To the different taxations } \\
\text { between dividends and } \\
\text { retained earnings }\end{array}$ & Other reasons & Non answered & Total \\
\hline No of firms & 31 & 20 & 25 & 45 & 121 \\
\hline
\end{tabular}

Table 4. (Q13)

\begin{tabular}{lr}
\hline Answers & No of firms \\
\hline The earnings after the financing of all the business plans with positive NPV & 37 \\
The outcome from a cash flow model which forecasts dividends of the near future & 10 \\
By analyzing the payout ratio of the major competitors & 1 \\
By analyzing the payout ratio of the sector & 4 \\
Other methods & 9 \\
Non answered & 60 \\
Total & 121 \\
\hline
\end{tabular}

Table 5. (Q4)

\begin{tabular}{|c|c|c|c|c|c|c|c|c|c|c|c|c|c|c|}
\hline \multicolumn{2}{|l|}{ Answers } & \multicolumn{3}{|c|}{$\begin{array}{l}\text { The risk of dividends } \\
\text { is greater than the risk } \\
\text { of capital gains }\end{array}$} & \multicolumn{4}{|c|}{$\begin{array}{l}\text { The risk of dividends is smaller } \\
\text { than the risk of capital gains }\end{array}$} & \multicolumn{3}{|c|}{$\begin{array}{l}\text { The risk of dividends } \\
\text { is equal to the risk } \\
\text { of capital gains }\end{array}$} & \multicolumn{2}{|c|}{ Non answered } & \multirow{2}{*}{$\begin{array}{l}\text { Total } \\
121\end{array}$} \\
\hline No of fir & & 7 & & & 61 & & & & 36 & & & 17 & & \\
\hline \multicolumn{15}{|c|}{ Table 6. (Q7) } \\
\hline Answers & Up to $10 \%$ & $11-20 \%$ & $21-30 \%$ & $31-40 \%$ & $41-50 \%$ & $51-60 \%$ & $61-70 \%$ & $71-80 \%$ & $81-90 \%$ & 91-100 & More & $100 \%$ & Non ans/red & Total \\
\hline $\begin{array}{l}\text { No } \\
\text { of firms }\end{array}$ & 31 & 10 & 13 & 23 & 10 & 2 & 5 & 4 & 4 & 2 & 3 & & 14 & 121 \\
\hline
\end{tabular}

Table 7. (Q8)

\begin{tabular}{lllllll}
\hline & $\begin{array}{l}\text { Constant } \\
\text { payout ratio }\end{array}$ & $\begin{array}{l}\text { Constant portion } \\
\text { of money per share }\end{array}$ & $\begin{array}{l}\text { Constant amount of } \\
\text { money which is increasing } \\
\text { with a constant rate }\end{array}$ & $\begin{array}{l}\text { Low regular dividend } \\
\text { plus an extra dividend } \\
\text { payment }\end{array}$ & $\begin{array}{l}\text { No criteria } \\
\text { at all }\end{array}$ & Other \\
\hline No of firms & 40 & 14 & 20 & 6 & 29 & 12 \\
\hline
\end{tabular}

In the Likert's five scale, with 1 representing the "not important at all" and 5 the "highly important", the mean score was 3.57 and the mode 4 , with 71 firms scoring 4 (51 firms) and 5 (20 firms), i.e., very and high important. This result introduces another parameter that is quite important and connects the dividend policy with the investment policy of the firm. Thus, in the short run the majority of the sampled firms take into account their expected earnings, i.e., the investments' potential net earnings.

Additionally, we measure the effect of another parameter, which was first introduced by Lintner (1956) and proved to be statistically important in many other researches on dividend policy (For example, Frankfuter and Junior (2002; Allen and Michaelly, 1995) the dividend policy of the previous year. Question 10 (Q10) (Table 2) asks the management team to ... "Rate the importance of the dividend policy followed by the firm in the past" in determining the current payout policy. According to our findings most of the Greek firms noted that the past dividend choices affect the present dividend payment. This result can be explained by two different, but not conflicting, ways. On one hand, the firm does not want to create any kind of distress (risk) to shareholders by continuously changing the dividend payments. On the other hand, the affection of past dividend might be a long run result reflecting a target payout ratio by the firm, which is adjusted in the short run according to the current position of the firm. The question 10 results are supported by the result of question 11 (Q11) (Table 2), where we asked the firms: "How important is it for the dividend policy of your company the following sentence: The company should avoid making changes in dividend payments, which might be reversed within one or two years?" 47 firms reported that this is an important statement for their company; on the contrary 36 firms state that this statement is not important for their dividend decision making; whereas 33 firms rate this statement as moderate importance. The overall impression is that the majority of the firms decide about 
their current dividend payment considering the future dividend payments and their ability to support this dividend policy in the long run.

Influenced by many researches (section 2) we asked the Greek firms about their dividend policy in the long run (Q12) (Table 1): "Has the firm a long run payout ratio as target?" The $43 \%$ of the firms answered that they have a long run target payout ratio, the $47.9 \%$ that they have not and the remaining percentage did not want to answer the question probably to information discloser. This result does not either rejects or confirms the target payout ratio supporters. Additionally, this result separates the firms in two categories, those who program their investment, capital structure and dividend policies and those who, at least, do not program their payout policy. Given that the three financial decisions (i.e., investment, capital structure and dividend decisions) are closely related, we recognize that a firm, with long run dividend policy, has already sketched its future investment and financing. In such a context we additionally asked the firms (Q13) (Table 4): "If the firm has a long run target payout ratio how does the firm determine it?" 37 firms note that they determine their long run dividend policy as the residual earnings after investing to all investment programs with positive net present value. 10 firms report that they decide their long run policy using a cash flow forecasting model, with dividend payments the portion of the earnings that they can not be invested in programs with positive net present value. This result suggests that one of the key factors in distribution of profits is the earnings left after the determination of all the current and the future investment programs. Additionally, some firms note that they also take into account the dividend distribution of the sector where they belong and some other that they take into account the dividend policy of their competitors. In question number 14 (Table 2) we asked the firms to denote the relevant importance of the following statement in their decision making (Q14): "The company must have a target payout ratio towards to which it drives its dividend policy, year by year". According to our findings, 52 firms level of the above statement as of moderate importance, 56 as of above the average importance and 11 as of below the average importance.

\subsection{Agency Theory and Dividend Policy}

As we analyzed in the theoretical part of this article, the agency theory refers to the relationships which are developed (a) between the debtors of the firm and the firm and (b) between the management team and the shareholders. Our first question related to agency theory concerns the relation between the firm and its debtors.
The borrowing of money and the cost of borrowing are directly related to the firm's market reliability. It is true that many lenders ask their clients, directly or indirectly, to impose restrictions related to their dividend payments; it is also true that many firms unofficially and by their own decision restrict their dividend payments in order to borrow money easily. Thus, we ask the firms to denote (Q15) (Table 2): "How the dividend policy of the firm is affected by its ability to borrow money?" Our findings proved to be confusing since there is not a dominate answer. 40 firms note that they do not believe that their borrowing ability is affected by their dividend choice whereas 52 firms believe that there are affected by their dividend policy. Given that the financing of a project is constituted by internal and external financing we additionally asked the firms to rate the importance of the following statement (Q16) (Table 2): "The financing of new investment projects does not affect the dividend policy of the company?" Our findings are complicated since 40 firms rate the importance of this statement as moderate, 45 as above average and 31 below average.

According to agency theory the dividend policy affects the relationship among owners, management team and debtors. Changes on dividend payments may stagger the relationship among them. This means that smooth and consistent dividend payments will be valued more and will decrease the agency cost, since dividend payments will not affect their relation unexpectedly. Thus, we asked the firms to tell us (Q17) (Table 2) "How important is for the firm to have smooth and consistent dividend payments?" 44 firms denote that this statement is important for their firm and 44 rate this statement as of moderate importance for the firm. Additionally, 18 companies rate the statement as of high important and 13 as of low importance.

Another parameter that affects the agency cost is the liquidity of the firm. It affects the relationship between both, the shareholders and the management team and the firm and its debtors. On one hand, the shareholders want to minimize the free cash of the firm in order to press the management team to use the available capital more effectively, on the other hand the debtors of the firm value positively the existence of free capital in the firm since free capital works as guarantee that the firm will at least meet its short run obligations. The distribution of dividend means, possibly, a short run, decrease in the liquidity of the firm. Our next question asks the firms (Q18) (Table 2): "How important is for the dividend policy of the firm its liquidity?" Our findings proved to be very interesting since the Greek firms consider their 
liquidity as a very important parameter which affects their dividend decision making. More specifically, the $89.1 \%$ of the firms rated the importance of liquidity from moderate importance to very high importance.

\subsection{Information Content of Dividend}

The dividend information theory assumes that dividend payments contain information concerning the value of the firm. In our empirical investigation we asked the firms a number of questions regarding the information content on dividend. Firstly, we asked (Q19) (Table 2) the companies to tell us how important to their dividend policy the following sentence is: "The market uses the company's dividend announcements as information on the valuation of its stocks". The more important the statement is for the dividend policy, the more likely companies will ensure the dividend policy in order not to pass negative signals to the market. Moreover, the more significant the statement is, the greater the validity of the signaling theory. According to our findings, 74 firms rated this statement as important, whereas 43 firms rated it as not so important for their dividend policy. Additionally, in order to identify and record the relationship between dividend policy and signaling theory and check what companies believe for dividend policy as a mean of transferring information to the market, we asked our firms to answer the following question (Q20) (Table 2): "Do you think that the market uses the dividend announcements of the company as information to assess the value of its stock? $19.2 \%$ of companies believe that the market does not use the information dividend as a mean to assess the value of its stock, $40 \%$ reports that it happens sometimes, $27.1 \%$ that it happens usually, $15 \%$ several times and finally $4.2 \%$ always. We see, that the $80.8 \%$ of the firms admits, either sometimes or often, that the market uses the dividends as a mean of information to evaluate the value of the share of the firm. These initial results can be regarded as key evidence that the signaling theory is confirmed, to some extent, by the firms themselves.

One of the most intensive dividend corporate happenings is an unexpected increase or decrease in dividend payments. Thus, we asked the firms to answer the following question (Q21) (Table 1): "How an unexpected increase in the dividend of the company is perceived by the investors?". The majority of respondents, $51.3 \%$, answered that investors believe that an unexpected increase in dividend is a positive sign. The reason is obvious, since shareholders receive more revenue than what was expected, is reasonable to be a positive sign for the company and its prospects. In contrast,
$25.2 \%$ of businesses consider that such a move is seen from the perspective of shareholders as negative information. Their choice can be explained under the assumption that firms increase their dividends unexpectantly only when they do not have appropriate investments to invest the released (free) capital. Additionally, we asked (Q 22) (Table 1) the firms: "How an unexpected decrease in the dividend of the company is perceived by the investors?" $50 \%$ of the respondent firms indicate that investors believe that an unexpected reduction in the dividend is a negative signal to investors. The reason is obvious; since shareholders do not receive the expected income from the company it is a direct indication that something is wrong with the company, which is not in a position to distribute the expected earnings. On the other hand, $27.1 \%$ of businesses consider that such a move is seen from the perspective of shareholders as positive information. A possible explanation is that investors may consider that the unexpected reduction in the dividend is mainly due to the finding additional efficient investments for the firm, which was funded directly by using the firm's profits. Finally, $22.9 \%$ of businesses consider that an unexpected reduction in the dividend shall be considered neither negatively nor positively by investors, who appear to be indifferent about whether to take a smaller dividend and what this may mean.

The decision by the company not to pay cash but to proceed to repurchase shares involves possible information to investors about the future prospects of the company. Thus, we asked the firms (Q23) (Table 1): "Is a repurchase of shares by the company an indication to the investors?" 118 firms chose to answer this question. The $55.4 \%$ of them reported that indeed this policy gives an indication to investors about future prospects. In contrast, $22.9 \%$ said that buying back shares does not show anything, while the remaining 20.3\% did not want to answer. We supplementary asked (Q24) (Table 1) the firms if the sign for the market of a share repurchase is positive, negative or neutral. Of the 75 companies that responded to this question, the $84.0 \%$ reported that the evidence provided by such a move is positive; negative $5.3 \%$ and $10.7 \%$ neutral. In a similar question (Q25) (Table 1) we asked the firms if "The issue of new shares by the company provides a signal to investors about its future prospects". In this question, 119 companies answered, of which $73.1 \%$ responded positively, $14.3 \%$ negative, while the remaining $12.6 \%$ said they did not wish to answer. Following this question, we wanted to see what indicates a new shares issue for the share holders. Thus, we asked (Q 26) (Table 1) the firms that responded positively to tell us if the issue of equity bears positive, negative or neutral information about the firm. In 
this question 89 companies responded, of which $89.9 \%$ said that the statement is positive about the future prospects of the company, negative $4.5 \%$ and $5.6 \%$ neutral.

Finally, we asked (Q27) (Table 2) the firms to rate the importance of the following statement in their dividend decision making: "The firm has to inform the shareholders about the reasons of a change in its dividend policy". 91 of the 119 companies that responded to the question consider the statement rather or very important, very few (23) firms reported moderate important, while only 5 consider the significance of this statement is below the moderate level.

\subsection{Economic Environment and Dividend Policy}

According to the literature review and the empirical findings of this study, there are many different theories concerning the dividend policy of the firms. Additional to these theories, the economic environment affects the corporate decision of the firm in many ways. In our empirical investigation we asked the Greek firms how important are some major economic parameters in their payout decision making. Our first question (Q28) (Table 2) asks the firms to rate the importance of taxation in their dividend decision making. The results of this question are confusing since 45 from the 121 firms rate the importance of this factor as low and 62 as high.

Another important factor that may affect the dividend policy of the firm is the capital market, which reflects the economic environment of the firm and the potentials of the economy. Thus, we asked the firms to answer the following question (Q29) (Table 2): "How important is for your dividend decision making the capital market's conditions?" According to our findings, the $35 \%$ of the firms regards this factor as important and the $24 \%$ as very important. Of course, there is a small percent of $18 \%$ which considers this factor not important for their dividend policy. A supplementary to capital market conditions factor, which reflects the flexibility of the economic environment, is the legal framework of the Greek economy. Thus, we asked the firms to answer (Q30) (Table 2): "How important for your dividend policy is the legal framework of the country?". The majority of the firms (81 firms) answered that it is important for their dividend policy the restrictions imposed by the law.

The last factor that we took into account in our empirical analysis of the economic environment is inflation. Inflation affects the purchasing power of the final consumer, in our case the dividend receiver. The greater the inflation the lower the purchasing power of the dividend. The only way to avoid this real income reduction is to adjust the dividends for inflation. In our related question (Q31) (Table 2) we asked the firms to rate the importance of the inflation in their dividend choice. The results of this question proved to be complicated since the Greek firms seem to have a variety of opinions concerning the inflation and their dividend decision making.

\section{DISCUSSION}

In section 3 we presented our findings from the Greek market. In this section we compare our results with four similar articles that analyze the dividend policy of firms using questionnaires. These four articles focusing in five different markets, the NYSE firms by Baker and Powell (1999), the British firms by Dhanani (2005), the Norwegian firms by Baker et al. (2006) and the NASDAQ firms by Baker et al. (2001). This section, section 4 , is divided to five subsections corresponding to the five subsections of sections 2 and 3.2.

\subsection{The Value of the Firm}

The results consistently produce strong support for the hypothesis that dividend affect the value of the firm. According to our findings, the majority of our sample firms denote that the market value of the firm is affected by their dividend policy. The main reason for this relationship is that dividend payments are less risky than retained earnings. Additional findings support that Greek firms believe that investors consider both the return of their investment and its underling risk, with dividends being the safest part of their return. Our findings are in line with Baker et al. (2006), who reported that one of the main factors that Norwegian firms take into account is dividend payments, since they consider future capital gains riskier. In their research, Baker and Powell (1999), reported that the majority of the sampled firms believes that dividend policy affects the share price. Similar findings were reported by Dhanani (2005) for British firms, according to which, firms can adjust their dividend policy in order to maximize the shareholders' wealth. Baker et al. (2001) reported that NASDAQ sample firms accept the relation between dividends and share price but it does not seem that these firms use dividend as a mean of price affection.

\subsection{Corporate Dividend Policy Decisions}

According to our findings most of the Greek firms design their dividend policy based on their current earnings. More than that, we find that the dividend payments history of the firm, as first introduced by Lintner (1956), is an important parameter; firms do not 
want to surprise investors with rapid and large dividend changes, positive or negative, since it increases the risk (variance) of the investors' income. The importance of dividend history has also been highlighted by Baker and Powell (1999) for NYSE firms, Dhanani (2005) for the British firms and Baker et al. (2006) for the Norwegian firms. Additionally, Baker et al. (2001) findings, for NASDAQ firms, are in line with our results on past dividend importance; they also find that the sector of the firm, affects its dividend decision making.

Another important finding is that most of the Greek firms agree with Lintner (1956) on target payout ratio and distinguish dividend policy in short and long run periods. On the contrary Baker et al. (2001) do not report target payout ratio as an important factor. Target payout ratio is also considered by Baker et al. (2001), but they do not rank it as of a high importance factor. On the contrary Baker et al. (2006) report that the management teams of the Norwegian firms do not seem to consent with the target payout ratio. At this point it is necessary to highlight that according to our findings, even though many firms are willing to employ a target payout ratio, only the $43.3 \%$ of them recognize that it actually uses one.

\subsection{Information Content of Dividends}

According to our findings, Greek firms, in general, believe that the market uses their dividend payments to determine the value of the firm. In more detail, $61,7 \%$ of the sample firms denote that at least some times, market uses dividend payments to determine the share price whereas the $35,2 \%$ of them believe that market uses their dividend payments more often. Additionally, we have strong evidence that support the signaling theory; the $76.5 \%$ of the Greek firms consider important for their dividend policy to explain any change in dividend payments to shareholders. Our findings are in line with Baker and Powell (1999) for the NYSE firms, Baker et al. (2006) for the Norwegian firms and different from NASDAQ firms (Baker et al., 2001) which believe that the information content in dividends is rated from moderate to low importance.

In contrast to our initial belief that the typedirection-of the signal is not easily determined, our findings reveal that most of the Greek firms agree that an increase in dividend carries out a positive type of signal, whereas a decrease a negative one. Our results are similar with that of Baker et al. (2006) for Norway and Dhanani (2005) for Brittan. Ranking our signaling findings, the strongest market signal is conveyed by an increase in capital, whereas share repurchase comes second and stock split third. It is worth mentioning that, according to our results, the inverse stock split does not convey any type of information.

\subsection{Agency Theory of Dividends}

According to Baker and Powell (1999) evidence in agency theory is hazy. Dhanani (2005) reports that British firms do not consider dividend payments as a borrowing holdback and from shareholders' point of view it is more beneficial to lower their dividend income (through a contract) and borrow. Our empirical findings support agency theory and disclose the efforts of the Greek firms to avoid restrictions on their capital, with possible obligation sources: The borrowing contracts, the market restrictions and their ability to borrow inexpensively and uncommitted. Baker and Powell (1999) report significant evidence that dividends force NYSE firms to external financing. These results are in line with ours since Greek firms denote that the availability of cash is important in their dividend choice. Additionally, Baker et al. (2006) rank the external financing and the possible liquidity limitations among the five most important factors that affect dividend policy. However, Norwegian firms (According to, Baker et al., 2006) do not consider any type of corporate commitment, as important dividend factor, due to external financing. Low to moderate evidence of the dividend agency theory can be found in NASDAQ firms, Baker et al. (2001). According to their findings the level of leverage, the availability of borrowing sources and the possible liquidity restrictions are not important for their dividend policy.

\subsection{Economic Environment}

According to our findings the economic environment, as described in section 2, affects the dividend policy of the firms. First of all, we find an ambiguous impact of tax on dividend policy; the $37.2 \%$ of the Greek firms reports that tax does not affect their dividend choice, whereas the $58.9 \%$ of the sample firms considers it as an important factor. These equivocal findings might be a result of the Greek tax system, as dividends were not taxable, before the economic crisis and the final dividend cash outflow has already been reduced since dividend is a portion of the after tax earnings. Another interpretation of this result is that firms answer the questionnaire keeping in mind that a tax on dividends is about to be imposed. Our findings are similar to Dhanani (2005) for the British firms. The findings of (Baker et al., 2001; 2006) support that for NASDAQ and Norwegian firms' taxation has small impact on their dividend policy. The 
legislation system for the Greek market, in contrast to (Baker et al., 2001), proved to be more important factor than taxation. Our findings report that the $68.6 \%$ of the Greek sampled firms ranks the legal system from important to very important for dividend policy. These results were expected since, in Greece, law forces firms to distribute at least $35 \%$ of their current net earnings (Germany, Switzerland, Brazil and several other countries have institutional features similar to Greece). On the contrary, inflation rate does not seem to affect dividend decisions. This result can be explained easily since earnings are automatically adjusted to inflation.

\section{CONCLUSION}

In this article we analysed the dividend policy of the Greek firms listed in Athens Stock Exchange (ASE) prior to the economic crisis in Greece. We gathered our primary data by sending out questionnaires to all firms listed in Athens Stock Exchange, from the 355 listed firms in January 2004 (121 firms responded positively). Additionally, we compared our results with the findings of four other studies concerning the firms listed on NYSE, NASDAQ, British firms and Norwegian firms. Our empirical findings concerning the dividend policy of the Greek firms prior to the Greek economic crisis proved to be very interesting since there are similarities and differences between the dividend policy of the Greek firms and other countries. More specifically, the average listed Greek firm shares the same opinion with the average firm of the compared studies in the following areas: Price affection, risk bearing, past dividends' pattern and agency costs. Some of our findings proved to be quite close with some of the results of the compared studies in the following subjects: The sector of the company, the target payout ratio, the financing ability and the information content of dividends. Finally, some of our findings are in contradiction to some of the results of other studies, these are: The impact of taxation on dividends and the legislation framework.

At this point it is necessary to report some major limitations and suggestions resulted from this study. First of all, the questionnaires cover only one year, thus changes in the dividend policies cannot be measured. Normally, the results of the questionnaire could be the same, in the short run given that nothing has affected the market in such an extent; but the economic crisis that the global economy faces and the intensive local crisis of Greece would probably have changed the answers of the questionnaire dramatically. Second, it is true that the collection of an updated questionnaire is quite necessary for comparison reasons. The fact that our collection period is accomplished five years ago, even that it seems to be a disadvantage, provides us with the ability to send out the same questionnaire within this financial year in order to find the impact of the economic crisis on the dividend policy of the Greek firms. Last but not least, it would be interesting to sent out the same questionnaire after the Greek economic crisis; the collection of such a questionnaire would result in both, recording the dividend policy of the firms of a country before, in the middle and after a major economic crisis and compare the changes in time.

\section{REFERENCES}

Allen, F. and R. Michaely, 1995. Dividend policy. Handbooks Operations Res. Manage. Sci.

Baker, H., T. Mukherjee and O.G. Paskelian, 2006. How Norwegian managers view dividend policy. Global Finance J., 17: 155-176. DOI: 10.1016/j.gfj.2006.06.005

Baker, H. and G.E. Powell, 1999. How corporate managers view dividend policy. Q. J. Bus. Econ., 38: 17-19.

Baker, H., E.T. Veit and G.E. Powell, 2001. Factors influencing dividend policy decisions in NASDAQ firms. Financ. Rev., 38: 19-39. DOI: 10.1111/j.1540-6288.2001.tb00018.x

Baker, K., G. Farelly and R. Edelman, 1985. A survey of managers views on dividend policy. Financ. Manage., 14: 78-84. DOI: 10.2307/3665062

Baker, H.K., G.E. Farrelly and R.B. Edelman, 1985. A survey of management views on dividend policy. Financ. Manage., 14: 78-84. DOI: 10.2307/3665062

Balachandran, B. and A.T. Nguyen, 2004. Signalling power of special dividends in an imputation environment. Account. Finance, 44: 277-297. DOI: 10.1111/j.1467-629x.2004.00112.x

Beer, M.F., 1993. Dividend signalling equilibria: Quantitative evidence from the brussels stock exchange. Financ. Rev., 28: 139-157. DOI: 10.1111/j.1540-6288.1993.tb01342.x

Benartzi, S., R. Michaely and R. Thaler, 1997. Do changes in dividends signal the future or the past. J. Finance, 52: 1007-1034. DOI: 10.1111/j.15406261.1997.tb02723.x

Bernhart, D., A. Douglas and F. Robertson, 2005. Testing the signalling models. J. Empirical Finance, 12: 77-88. DOI: 10.1016/j.jempfin.2003.10.002

Black, F., 1976. The dividend puzzle. J. Portfolio Manage., 2: 5-8. DOI: 10.3905/jpm.1976.408558 
Black, F. and M.S. Scholes, 1974. The effects on dividend yield and dividend policy on common stock prices and returns. J. Financ. Econ., 1: 1-22. DOI: 10.1016/0304-405X(74)90006-3

Brennan, M., 1970. Taxes, market valuation and financial policy. National Tax J., 23: 417-427.

Brook, Y., W.T. Charlton and R.J. Hendershott, 1998. Do firms use dividends to signal large future cash flow increases? Financ. Manage., 27: 46-57. DOI: $10.2307 / 3666274$

DeAngelo, H. and L. DeAngelo, 2006. The irrelevance of MM dividend irrelevance theorem. J. Financ. Econ., 79: 293-315. DOI: 10.1016/j.jfineco.2005.03.003

DeAngelo, H., L. DeAngelo and D.J. Skinner, 1996. Reversal of fortune: Dividend signaling and the disappearance of sustained earnings growth. J. Financ. Econ., 40: 341-371. DOI: 10.1016/0304405X(95)00850-E

DeAngelo, H., L. DeAngelo and D.J. Skinner, 2000. Special dividends and the evolution of dividend signaling. J. Financial Econ., 57: 309-354. DOI: 10.1016/S0304-405X(00)00060-X

Denis, D.J. and I. Osobov, 2008. Why do firms pay dividend? International evidence on the determinants of dividend policy. J. Financ. Econ., 89: 62-82. DOI: 10.1016/j.jfineco.2007.06.006

Dhanani, A., 2005. Corporate dividend policy: The views of British financial managers. J. Bus. Finance Account., 32: 1625-1672. DOI: 10.1111/j.0306686X.2005.00643.X

Dyl, E.A. and R. A. Weigand, 1998. The informational content of dividend initiations: Additional evidence. Financial Manage., 27: 27-35.

Easterbrook, F., 1984. Two agency cost explanations of dividends. Am. Econ. Rev., 74: 650-659.

Elton, E. and M. Gruber, 1970. Marginal shareholder tax rates and the clientele effect. Rev. Econ. Stat., 52: 68-74. DOI: $10.2307 / 1927599$

Fama, E. and H. Babiak, 1968. Dividend policy: An empirical analysis. J. Am. Stat. Associat., 63: 11321161. DOI: $10.1080 / 01621459.1968 .10480917$

Fama, E.F. and K.R. French, 2001. Disappearing dividends: Changing firm characteristics or lower propensity to pay? J. Financ. Econ., 60: 3-44. DOI: 10.1016/S0304-405X(01)00038-1

Fildeck, G. and J.D. Mullineaux, 1999. Agency cost and dividend payments the case of bank holding companies. Q. Rev. Econ. Finance, 39: 409-418. DOI: 10.1016/S1062-9769(99)00008-3
Frankfurter, G.M. and W.R. Lane, 1992. The rationality of dividends. Int. Rev. Financ. Analysis, 1: 115-129.

Frankfuter, G.M. and W.B.G. Junior, 2002. Dividend policies and their empirical test. Int. Rev. Financ. Analysis, 11: 111-138. DOI: 10.1016/S10575219(02)00071-6

Fuller, P.K. and M.B. Blau, 2010. Signalling, free cash flow and "non monotonic" dividends. Financ. Rev., 45: 21-56. DOI: 10.1111/j.1540-6288.2009.00236.x

Fuller, P.K. and A.M. Goldstein, 2011. Do dividends matter more in declining markets. J. Corporate Finance, 17: 457-473. DOI: 10.1016/j.jcorpfin.2011.01.001

Gordon, M.J., 1963. Optimal investment and financial policy. J. Finance. DOI: 10.2307/2977907

Jensen, M., 1986. Agency cost of free cash flow, corporate finance and takeover. Am. Econ. Rev., 76: 323-329.

Kalantonis, P. and C. Zopounidis, 2009. Exploring and evaluating the innovation process and innovative effort of companies through their financial reports. Small Business Innovation.

Kalay, A., 1982a. Stockholders-bondholder conflict and dividend constrains. J. Financ. Econ., 10: 211-233.

Kalay, A., 1982b. The Ex-dividend day behavior of stock prices: A re-examination of the clientele effect. J. Finance, 37: 1059-1070. DOI: 10.1111/j.15406261.1982.tb03598.x

Kalay, A. and R. Michaely, 1993. Dividend and taxes: A reexamination. University of Utah, Salt Lake City, Utah.

Lease, C.R., K. John, A. Kalay, U. Loewenstein and H.O. Sarig, 2000. Dividend Policy its Impact on Firm Value. 1st Edn., Harvard Business School Press, Boston, ISBN-10: 0875844979, pp: 219.

Lintner, J., 1956. Distribution of incomes of corporations among dividends, retained earnings and taxes. Am. Econ. Rev.

Lintner, J., 1956. Optimal dividends and corporate growth under uncertainty. Q. J. Econ., 78: 49-95. DOI: $10.2307 / 1880545$

Lintner, J., 1962. Dividends, earning, leverage, stock price and the supply of capital to corporations. Rev. Econ. Stat., 44: 243-269. DOI: 10.2307/1926397

Lipson, M.L., C.P. Maquieira and W. Megginson, 1998. Dividend initiations and earnings surprises. Financ. Manage., 27: 36-45. DOI: 10.2307/3666273

Litzenberger, R. and K. Ramaswamy, 1979. The effects of personal taxes and dividends on capital asset prices: Theory and empirical evidence. J. Financ. Econ., 7: 163-195. DOI: 10.1016/0304405X(79)90012-6 
Miller, M.H., 1986. Behavioural rationality on finance: The case of dividends. J. Bus., 59: 451-468. DOI: 10.1086/296380

Miller, M.H. and F. Modigliani, 1961. Dividend policy, growth and the valuation of shares. J. Bus., 34: 411433. DOI: $10.1086 / 294442$

Miller, M.H. and M.S. Scholes, 1978. Dividends and taxes. J. Financ. Econ., 6: 333-364. DOI: 10.1016/0304-405X(78)90009-0

Nakamura, A. and M. Nakamura, 1985. Rational expectations and the firms dividend behaviour. Rev. Econ. Stat., 67: 606-615. DOI: 10.2307/1924805
Poutos, I.E., 2009. The financial factors and the accounting implications of dividend policy: An empirical analysis of the Greek listed firms in the Athens exchange. $\mathrm{PhD}$ Thesis, Hellenic Open University.

Twu, M., 2012. Stock market development and the decline of the portion of dividend payers throughout the world. Financ. Rev., 47: 401-421. DOI: 10.1111/j.1540-6288.2012.00334.x

Yoon, P.S. and L.T. Starאs, 1995. Signaling, investment opportunities and dividend announcements. Rev. Financ. Stud., 8: 995-1018. DOI: $10.1093 / \mathrm{rfs} / 8.4 .995$ 